\title{
'n Ondersoek na die taalgebruik in Son as verteenwoordigend van Kaaps
}

Joline Blignaut en Harold Lesch

Departement Afrikaans en Nederlands, Universiteit Stellenbosch, Suid-Afrika

E-pos: joline.blignaut@gmail.com; hlesch@sun.ac.za

\section{Opsomming}

Kaaps is een van die oudste variëteite van Afrikaans wat sedert die sewentiende eeu aan die Kaap gepraat is en is vandag steeds die taal van die bruin werkersklas in die Kaapse Skiereiland. Alhoewel dit hoofsaaklik as 'n gesproke variëteit gebruik word, word dit ook aangewend in die letterkunde. Dis veral die gebruik van Kaaps in die digkuns en drama van Adam Small wat Kaaps help vestig het in die Afrikaanse literatuur en 'n nuutgevonde belangsteling in dié variëteit van Afrikaans gebring het. Vandag vind Kaaps neerslag in die teater, musiek, televisie, radio en die gedrukte media. Die doel van die studie is om die gebruik van Kaaps in die poniekoerant Son te ondersoek. Die studie wil bepaal tot watter mate Kaaps in die Son-artikels gebruik word en tot watter mate diglossie voorkom in Son deur die gebruik van Kaaps en Standaardafrikaans in een artikel of binne een uitgawe van Son. Die taalvariasie in Son word vanuit 'n sosiolinguistiese raamwerk ondersoek as verteenwoordigend van Kaapse Afrikaans. Binne die raamwerk word taal binne die sosiale konteks waarbinne dit voorkom ondersoek. 'n Gelykevlakbenadering tot taalvariasie word gevolg waar Kaaps beskou word as deel van die spektrum van Afrikaans en nie as ondergeskik tot die standaardvariëteit nie. Son is die eerste Afrikaanse poniekoerant in Suid-Afrika en die eerste koerant wat 'n informele vorm van Afrikaans gebruik wat deur sommige beskou word as Kaaps. Die doel van die studie is om die taalgebruik in Son te ondersoek in 'n poging om te bepaal tot watter mate die taalgebruik in Son 'n getroue weerspieëling van Kaaps is en tot watter mate dit ooreenstem met die taalgebruik van die sprekers van Kaaps. Die ondersoek word gedoen deur 'n teksanalise van Son-artikels uit verskillende uitgawes van Son. Die bevinding van die studie is dat die taalgebruik in Son nie beskou kan word as 'n ware weerspieëling van Kaaps nie, maar eerder as 'n informele Afrikaans wat elemente van Kaaps bevat.

Sleutelwoorde: Kaaps, sosiolinguistiek, poniekoerante, Son, diglossie

\section{Research to establish whether the language usage in Son is indicative of Kaaps}

\section{Extended abstract}

Kaaps is one of the oldest dialects of Afrikaans that originated in the Cape Colony during the seventeenth century and is still used today by the working class Coloured community of the Cape Peninsula. 
Although Kaaps is used mainly as a spoken dialect, it is also applied in the literature. In the 1940s, Kaaps was applied in the prose of S.V. Petersen and later, in the 1960s in the work of Adam Small who established Kaaps in the Afrikaans literature and brought a newfound interest in the dialect. Today the use of Kaaps in its written form is no longer restricted to the literature, but is also reflected in theatre, music, television and the printed media. The focus of this study is to investigate the use of Kaaps in the Afrikaans tabloid, Son.

Studies of the written representation of Kaaps are mainly restricted to research that examined the use of this dialect in literature or drama. This includes studies by Hendricks (1978) and Coetzee (2005). A linguistic examination of the use of Kaaps in tabloids has not been conducted yet.

The aims of this study were to determine to what extent Kaaps is used in Son articles and to what extent the written language correlates with the spoken Kaaps, as its speakers use it, as well as whether it is representative of Kaaps. The study also aimed to determine to what extent a diglossic relationship exists in Son by the use of both Kaaps and Standard Afrikaans in one article or in one entire issue of Son.

This study followed a sociolinguistic approach to describe the relationship between language and society and examined language in the social context in which it is used. With this approach, Kaaps is no longer seen as inferior to the standard variety of Afrikaans, but rather as part of the greater spectrum of Afrikaans.

Son is the first and only Afrikaans tabloid in South Africa. It was published for the first time in 2003 as a weekly publication after which it became available as a daily newspaper in 2005 . Currently Son appears in the Western- and Eastern Cape and its target market is lower income Coloured Afrikaans communities.

According to Botha (2009), three characteristics distinguish tabloids from other newspapers, namely news themes, language and style. Tabloid articles cover stories about scandal, gossip, sex and crime, and use informal language and writing styles, as well as crude language.

Son contains community stories about issues that readers can identify with, for instance poverty, unemployment and gang- and drug related crime. An informal Afrikaans is used in Son that many regard as Kaaps. According to Edwin Lombard, assistant editor of Son, the journalists of Son aim to use a language in their articles that resembles the language that is used by its readers. Anastasia de Vries (2012) regards the language that is used in Son as an unedited language document of Kaaps "as she is spoken". Although many people view the language that is used in Son as Kaaps, no evidence could be found of linguistic investigation carried out to determine the extent to which the language that is used in Son correlates with the Kaaps used by its speakers.

A linguistic investigation into the language that is used in Son was done by means of a text analysis of various Son articles that appeared in different issues of Son. The investigation aimed to determine the extent to which Kaaps is used in Son and if the language that is used in Son can be regarded as representative of Kaaps. 
Kaaps is characterised by a substantial English influence. This includes mixing of English and Afrikaans lexemes, borrowing lexemes from English and the Afrikaansifying of English words e.g. [Jldœu] (although) or [xətra:i] (try). The lexicon also comprises influences from the Muslim community with words like salaam that is a greeting form in Kaaps. The use of existing words in new or extended meanings is also typical lexical markers of Kaaps. This includes words like gevaarlik (dangerous) or duidelik (clear) with the meaning of good or nice, e.g. Hy speel [xəfa:lək] (good) rugby. Furthermore Kaaps contains certain expressions that are characteristic of this dialect, for example Kom ons [ma:ts] (march) meaning let's go.

Phonological features of Kaaps include vowel raising, e.g. [uk] (ook); schwa lowering, e.g. [xakJm] (gekom); affrication, e.g. [dzəi] (jy) and post-vocalic /r/-deletion, e.g. [vek] (werk).

Syntactical features of Kaaps include the use of the definite article die (the) before names of localities and the doubling of in (in) as a preposition and postposition, e.g. Ek bly in die Lavender Hill in. Morphologically, Kaaps also varies from Standard Afrikaans. This involves the embedding of the Afrikaans past tense form (ge-) in the English word, e.g. ge-worry, as well as the redundant addition of post morpheme to adjectives, e.g. bietere, pronounced as [bitərə] for beter (better), oralster pronounced as [oralstə] for oral (everywhere), and to verbs like skrywe for skryf (write).

The findings of this study is contrary to the view of, among others, Lombard and De Vries (2012) that the language that is used in Son is not a true representation of Kaaps, but rather an informal Afrikaans that use elements of Kaaps.

The most important characteristic of the language that is used in Son is the mixing of English and Afrikaans words. English words appear frequently in the articles, e.g. "Die counsil kan mos ons subsidy wegvat en eerder vir ons grond gee" (Son, 31 October 2012, p.6) (The council can take away our subsidy and rather give us land). Although the mixing of English and Afrikaans is one of the most prominent features of Kaaps, the great extent of English influence is also the most prominent feature of demotic Afrikaans. Therefore the language that is used in Son cannot be regarded as exclusively Kaaps.

Linguistic features of Kaaps are also present in the articles of Son, but are not used as frequently as English words and elements. Linguistic features of Kaaps are restricted to lexical items and expressions. The following are examples of typical lexical markers and expressions that are used in Son articles: "Dansonnie mang lewenslank na rape" (Son, 1 November 2012, p.2) (Dance instructor sent to jail for life after rape) and "Van 2 tot 4 Maart gaan die ding ruk" (Son, 16 February 2012, p.2) (From the $2^{\text {nd }}$ to the $4^{\text {th }}$ of March things will get jolly). Although lexical markers of Kaaps are present in Son articles, English words are often used instead of their Kaaps lexical equivalent. Lexical markers of Kaaps that are used in the tabloid are also mainly restricted to the direct words of sources and readers and, to a lesser extent, to those of reporters.

The analysis of the language that is used in Son revealed that there is a link between the content of the article and the language that is used. Lexical markers and expressions of Kaaps are used in articles that deal with community stories, gossip- and sensational reports. Contrary to this, Standard Afrikaans is used in prime news and especially in sport reports. 
At a grammatical level, the language that is used in the articles of Son does not reflect the syntactical features of Kaaps. Except for the influence of English on the word formation of Afrikaans words, the morphological features of Kaaps are not reflected in the articles of Son. Phonological variations of Kaaps are rarely reflected in the spelling of words. In the few instances where phonological variations are used, they are applied for humour's sake or to draw attention.

Some articles of Son, such as the prime news and sport reports, are written exclusively in Standard Afrikaans. A diglossic relationship exists in Son articles, as well as in the entire issue of Son, in that some articles are written in the high variety (Standard Afrikaans), while other articles use a low variety or demotic Afrikaans that is an informal Afrikaans, with lexical markers of Kaaps. A diglossic relationship also exists in one article, as demotic Afrikaans is alternated by Standard Afrikaans expressions and words. This alternation between Standard Afrikaans, Kaaps and demotic Afrikaans is typical of the way the speakers of Kaaps alternate between these varieties of Afrikaans, which shows the linguistic repertoire of the speakers of Kaaps. By using different varieties of Afrikaans, the tabloid represents a bigger speaker corps and includes more readers.

Given the diglossic relationship that exists in Son and the absence of phonological, syntactical and morphological markers of Kaaps, as well as the absence of lexical markers of Kaaps in some articles and the low frequency which Kaaps words and expressions are used in other articles, the language that is used in Son cannot be seen as a true reflection of Kaaps, but rather as an informal demotic Afrikaans that use elements of Kaaps.

Keywords: Kaaps, sociolinguistics, tabloids, Son, diglossia

\section{Inleiding}

Son is die eerste en enigste Afrikaanse poniekoerant in Suid-Afrika ${ }^{1}$. Dit verskyn in 2003 aanvanklik as 'n weekblad waarna dit in 2005 as 'n dagblad beskikbaar word en tans slegs in die Wes- en Oos-Kaap verskyn. Volgens Edwin Lombard (Persoonlike korrespondensie, 2012), assistant-redakteur van Son, is dié koerant se teikenmark bruin lesers in die Wes- en Oos-Kaap in die LSM $^{2}$ 3-7-groep en is die doel van die koerant om dié lesers se drome, ideale, oorwinnings en prestasies aan die groot klok te hang.

Alhoewel poniekoerante reeds sedert die 19de eeu in Brittanje en die VSA bestaan, het poniekoerante eers onlangs, na die politieke veranderinge, in Suid-Afrika verskyn. Voor die demokratiese verkiesing in 1994, het die apartheidsregering koerante gemuilband deur streng wetgewing, sensuur, teistering en tronkstraf.

\footnotetext{
${ }^{1}$ Die Daily Voice, alhoewel 'n Engelse poniekoerant, het in die verlede ook 'n Afrikaanse weergawe uitgegee wat versprei is in dele van die Wes-Kaap wat strek van die Weskus tot die Suidkus, maar dié uitgawe is middel Julie 2014 gestaak.

${ }^{2}$ LSM (Living Standard Measure) is 'n metode wat deur die SAARF (South African Audience Research Foundation) gebruik word om die Suid-Afrikaanse mark volgens hulle lewenstandaard te segmenteer. LSM 1 verwys na 'n groep met die laagste lewenstandaard terwyl LSM 10 na 'n groep met die hoogste lewenstandaard verwys.
} 
Die eerste Suid-Afrikaanse poniekoerant, Sunday Sun, is in 2001 uitgegee, waarna Daily Sun, die eerste poniekoerant wat as dagblad verskyn het, gevolg het. Daarna het nog Engelse poniekoerante soos Daily Voice en Sowetan gevolg. Vandag is poniekoerante die grootste verkopers van koerante in Suid-Afrika en dit word besit deur groot mediamaatskappye soos Media 24 en Independent.

Poniekoerante of tabloids verwys nie net na die A3-formaat van die koerant nie, maar ook na die inhoud. Biressi en Nunn (2008:7) beskou poniekoerante as 'n koerant wat vermaak, menslike belang en kommersiële winsgewendheid prioritiseer en teenoor ernstige en sosiale verantwoordelike joernalistiek staan. Verder lok die sensasionele inhoud kritiek uit as gevolg van die voyeuristiese en skaamtelose uitbuiting van gewone mense. Daarom dat die algemene beskouing van baie mense volgens Örnebring en Jönsson (2008:23) is dat poniekoerante die standaard van die openbare diskoers verlaag deur vereenvoudiging en verpersoonliking, en dat dit op sensasie en skandale floreer.

Son se stories is egter volgens Smith (2012:49) nie net van sensasionele aard nie, maar dit bevat veral gemeenskapstories wat die lesers direk raak en wat nie in ander hoofstroomkoerante verskyn nie. Dit sluit stories in oor armoede, werkloosheid en bende- en dwelmverwante misdaad. Om die rede beskou Smith (2012:49) Son as "n spieël wat hulle (die lesers se) alledaagse omstandighede weergee".

Wat die taalgebruik betref, word 'n informele vorm van Afrikaans wat deur sommige as Kaaps beskou word, as skryftaal in Son gebruik. Volgens Edwin Lombard (2012) poog Son om die taal wat in die koerant gebruik word so na as moontlik aan die monde van die lesers te hou, met ander woorde om te skryf soos die lesers praat. De Vries (2012) beskou die taalgebruik van Son as "'n rou, ongeredigeerde taaldokument van Kaaps as she is spoken". Volgens navorsing deur Smith (2012:51), beskou die lesers van Son die taalgebruik in Son as 'n onsuiwer, plat Afrikaans, maar'n taal wat hulle (die lesers) self praat.

Vandag is Son die grootste verkoper van Afrikaanse koerante in Suid-Afrika en die grootste verkoper van dagblaaie in die Wes-Kaap. Son se sirkulasiesyfer in 2012 van 103056 is aansienlik hoër as sy Afrikaanse opposisie in die Wes-Kaap, nl. die breëbladkoerant, Die Burger se 63139 (Ads24 2012). De Vries (2012) dui daarop dat met die koms van Son die sirkulasiesyfers van hoofstroomkoerante soos Die Burger en Rapport opmerklik gedaal het, in teenstelling met die sirkulasiesyfer van Son wat bestendig gebly het en selfs groei getoon het. Sy vra die vraag of die rede hiervoor is dat Son meer bekostigbaar is (in 2013 is die prys van 'n Son slegs R3,20 teenoor Die Burger waarvan die prys op weeksdae net meer as dubbeld daarvan is, nl. R6,50) en of die taal wat gebruik word om die gemeenskapstories te vertel 'n deurslaggewende rol speel.

Kort ná die verskyning van Son in die Wes-Kaap, is die koerant met dieselfde Kaapse taalgebruik ook in die noordelike provinsies versprei, maar volgens De Vries (2012) het dit'n vroeë dood gesterf. Die mislukking van Son in die noordelike provinsies laat die vraag ontstaan of die taalgebruik van Son nie meer deurslaggewend is in Son se sukses as die inhoud van die koerant nie. 


\section{Doel van die studie}

Navorsing oor die gebruik van Kaaps in die geskrewe vorm, is hoofsaaklik beperk tot studies wat die gebruik van dié variëteit in die letterkunde of drama ondersoek, soos studies deur onder andere Hendricks (1978, 2012a), Coetzee (2005) en Erasmus (2006) asook studies wat die gebruik van Kaaps in gedrukte advertensies ondersoek (Saal en Blignaut, 2011). Alhoewel 'n linguistiese ondersoek na die gebruik van 'n Kaapse Engels/Afrikaans in die Daily Voice deur Matthews (2009) gedoen is, is die fokus van die navorsing hoofsaaklik op Kaapse Engels, eerder as Afrikaans aangesien die Daily Voice hoofsaaklik 'n Engelse poniekoerant is, maar Afrikaanse of Kaapse merkers bevat. 'n Taalkundige ondersoek na die gebruik van Afrikaanse variëteite, of meer spesifiek Kaaps, in poniekoerante is egter nog nie voorheen gedoen nie.

Alhoewel daar al heelwat joernalistieke navorsing oor poniekoerante gedoen is, behels dié studies ondersoeke na die inhoud van poniekoerante, eerder as die taalgebruik. Navorsing oor Son sluit in Christo van der Rheede (2011) se studie oor die rol wat Afrikaanse poniekoerante soos Son kan speel om die sosiale, opvoedkundige en ekonomiese waarde van Kaapse Vernakulêre Afrikaans te ontsluit. Alhoewel hy in die studie die taalgebruik van Son bespreek, lê die fokus daarop om Kaapse Afrikaans op 'n groter skaal te ontsluit en te bevorder, eerder as wat die taalgebruik taalkundig ondersoek word. Die taalgebruik van Son is dus tot op hede weinig nagevors.

Die doel van hierdie studie is om 'n taalkundige ondersoek te doen van Son in 'n poging om te bepaal tot watter mate die taalgebruik in Son 'n egte weerspieëling van Kaaps is. Verder wil die navorsing bepaal tot watter mate diglossie voorkom in Son deur die afwisseling van Kaaps en Standaardafrikaans binne een artikel en in een uitgawe van die koerant.

'n Sosiolinguistiese raamwerk word gevolg binne die studie. Binne die raamwerk word taalvariëteite, in hierdie geval Kaaps, beskryf soos wat dit voorkom binne spraakgemeenskappe. Die verwantskap tussen taal en die sosiale konteks waarbinne dit voorkom word ondersoek en gevolglik vereis dit'n sistematiese studie van die taal sowel as die gemeenskap of konteks om nie net die variasie te bespreek nie, maar ook die doel van die variasie.

Metodologies behels die studie 'n teksevaluering van verskeie Son-artikels uit 12 uitgawes wat verskyn het tussen 9 Desember 2011 en 14 Oktober 2013 om te bepaal watter Kaapse merkers voorkom in die taalgebruik van Son. Dit sal vasstel of die taalgebruik soos wat dit voorkom in die artikels en koppe van Son-artikels tiperend is van die taalgebruik van Kaaps en bepaal of dié taalgebruik 'n egte weerspieëling is van Kaaps, soos wetenskaplik beskryf. Die taalgebruik in die artikels sal ontleed word in 'n poging om te bepaal vir watter effek Kaaps gebruik word en of die aard van die artikel 'n invloed het op die taal wat gebruik word.

Die artikel sal as volg daar uitsien: Eerstens sal Kaaps as 'n variëteit van Afrikaans bespreek word waarna 'n bespreking van diglossie sal volg. Daarna word die taalgebruik in Son-artikels bespreek na aanleiding van die teksanalise. Ten slotte word die bevindinge van die studie bespreek en saamgevat. 


\section{Kaaps}

\subsection{Agtergrond}

Kaaps is 'n variëteit van Afrikaans wat met die ontstaan van Afrikaans in die sewentiende eeu oorspronklik as 'n vorm van Afrikaans ontstaan het en aanvanklik deur die slawe aan die Kaap gepraat is. Vandag is dit steeds 'n omgangstaal wat gepraat word deur 'n verskeidenheid gemeenskappe wat tydens apartheid as bruin geklassifiseer is.

Kaaps het volgens Hendricks (2012a:97) 'n geolektiese en sosiolektiese karakter. Geolekties kan Kaaps beskou word as die variëteit van Afrikaans wat hoofsaaklik beperk is tot die Kaapse Skiereiland en omgewing. Dis 'n omgangstaal wat histories verbind word met veral die BoKaap en Distrik Ses waar die Kaapse Maleier langer as 'n eeu in noue kontak en assosiasie met diverse groepe saamgeleef het en waar Kaaps sekere kenmerke aangeneem het waaraan dit vandag geëien kan word. Hiervandaan het dit as gevolg van die Groepsgebiedewet met verloop van tyd na die Kaapse Vlakte uitgebrei (Hendricks 1996, 2012a, 2012b).

Wat die sprekers van Kaaps betref, word kleur sterk gekoppel aan Kaaps in verskeie definisies en beskrywings deur akademici en taalkundiges. "Kaaps, (is) die Afrikaanse spreektaal van sommige bruin mense op die Kaapse Vlakte" (Kleinhans 1988). Anastasia de Vries (2006) beskou Kaaps as die "Afrikaans van die bruin mense in die Kaap." Kaaps kan dus beskou word as 'n kleurvariëteit van Afrikaans.

In die geskrewe vorm het Kaaps aanvanklik in die veertigerjare ontwikkel met die prosawerk van S.V. Petersen en later sedert die sestigerjare met die werke van onder andere Adam Small, Peter Snyders, Patrick Peterson, Marius Titus, André Boezak, Vernie Plaatjies, Melville Whitebooi, Loit Sôls, Nathan Trantraal, Ronelda Kamfer en Anastasia de Vries. Dis juis die aanwending van Kaapse elemente in Small se dramas en digkuns wat Kaaps in die letterkunde gevestig het en 'n nuwe belangstelling in die taalvariëteit laat ontstaan het.

Willemse $(2012: 1,7)$ kritiseer egter die gebruik van Kaaps in die Afrikaanse letterkunde en voer aan dat dit "formule-agtig" aangewend word aangesien dit hoofsaaklik staatmaak op fonetiese variasie en daardeur die waardigheid van Kaaps ondermyn. Hy voer aan dat skrywers ook gebruik moet maak van "kenmerkende spraakritmes, idiomatiese taalgebruik, spesifieke streeksleksikale items of semantiese meervlakkigheid, gepaste beelding, verskillende taalregisters of stilistiese bewustheid, die spanning tussen omgangs en formele taalgebruik, woordspeling, aspekte soos sintaktiese en morfologiese uitsonderlikhede en ja, ook fonetiese variasie."

\subsection{Linguistiese merkers van Kaaps}

Verskeie studies is alreeds gedoen oor die kenmerkende taalverskynsels van Kaaps. Hierdie studies sluit in die ontleding van gesproke Afrikaans deur die data-insameling van verskillende groepe sprekers van Kaaps deur Klopper (1983) en Kleinhans (1988) asook die ontleding van gesproke Kaaps deur tienersprekers (Saal en Blignaut 2011). Verdere studies sluit ondersoeke in na die taalverskynsels van Kaaps soos dit neerslag vind in die literêre werke van onder meer Adam Small, Peter Snyders en Loit Sôls deur Hendricks (1996, 2012a, 2012b) en Coetzee 
(2005). Vervolgens sal die fonologiese, leksikale, sintaktiese en morfologiese verskynsels van Kaaps belig word soos bespreek deur bogenoemde taalkundiges.

\subsubsection{Fonologiese verskynsels}

Kenmerkende uitspraakverskynsels wat voorkom in Kaaps sluit onder andere in vokaalverhoging van veral $[\mathrm{e}]>[\mathrm{i}]$, bv. [vit] x weet en $[\mathrm{o}]>[\mathrm{u}]$, bv. [uk] x ook; vokaalverlaging van [ə] > [a] in veral die ge- en -ig-morfeme, bv. [xakom] x gekom en [rextax] x regtig; postvokaliese [r]-weglating, bv. [ve:k] x werk; affrisering van [j] $>[\mathrm{d} 3]$ in sillabe-beginposisies, bv. [dzəi] x jy; palatalisasie by die verkleiningsuitgang, bv. [karəntfis] x karretjies; ontronding en die verkorting van [a:] > [a], bv. [gan] x gaan: (Hendricks 2012a:105, 2012b:3, Saal en Blignaut 2011:350, Coetzee 2005:42).

\subsubsection{Leksikale verskynsels}

Kaaps word gekenmerk deur 'n vermenging van Afrikaans en Engels. Hendricks (1996:8) beskou die vervlegting tussen Afrikaans en Engels wat voorkom in Kaaps as volg: "Uitings met 'n oorwegend Afrikaanse karakter en wat deurspek is met Engelse woorde of uitdrukkings en woordformasies wat deels Afrikaans en deels Engels is, word plek-plek afgewissel met uitinge wat in die geheel Engels of in die geheel Afrikaans is." 'n Voorbeeld van die vervlegting van Afrikaans en Engels, soos opgeteken tydens 'n verkennende empiriese ondersoek van Tienerkaaps, is die volgende: "Hulle gat djou guy en jokes maak va djou, van hulle gat sê djy's cheap as djy fake tekkies dra."

Die gebruik van Engelse woorde kan volgens Hendricks (2012a:103) direkte ontlenings wees, soos in bostaande voorbeeld, of kan leksikale items wees wat klankmatig verafrikaans is bv. kompliet $\mathrm{x}$ complete, kôs why $\mathrm{x}$ because why en nout $\mathrm{x}$ note.

Klopper (1983:286) dui daarop dat Engelse woorde veral gebruik word wanneer daar verwys word na "amptelike sake, werksaangeleenthede, tegniese uitvindsels, familieterme, gemoedswerkwoorde en gespesialiseerde handelinge", bv. court, law, magistrate, spanner, seamstress, cop, drugs, inject, outsmart, cheat, figure, ens. Die Engelse woorde word egter volgens Klopper (1983:286) met die Afrikaanse ekwivalent vervang wanneer werkersklas Maleier- of bruin sprekers met wit sprekers in gesprek is. Ook bruin Christene van 'n hoë klas, gee voorkeur aan die Afrikaanse woorde in plaas van die Engelse ekwivalente in hulle gesprekke.

Navorsing deur McCormick (1993) oor die "vernakulêre Afrikaans" van die gemeenskap van Distrik Ses dui ook op die hoë frekwensie waarteen Engelse leenwoorde voorkom. Volgens haar is dit die gevolg van die taalkontak tussen Afrikaans en Engels wat oor 'n lang periode aan die Kaap plaasgevind het. Kodewisseling en kodevermenging ("mixing") is volgens McCormick so 'n belangrike eienskap van Kaaps dat sy, in teenstelling met ander taalkundiges soos Hendricks (1996), Klopper (1983) en Coetzee (2005), die taal van die bruin mense in die Kaapse Skiereiland as 'n gemengde kode ("mixed code") eerder as 'n variëteit van Afrikaans, nl. Kaaps, beskou (Deumert 2004:126).

Die leksikale variasie van Kaaps, is egter nie net beperk tot die vervlegting van Afrikaans en Engels nie, maar volgens Hendricks (2012a:103) en Kleinhans (1988) kom daar ook heelwat 
Islam-woorde of uitdrukkings in Kaaps voor. Die leksikale items het hulle oorsprong in die slawegemeenskap van die agtiende eeu aan die Kaap. Leksikale items wat vandag nog veral in die spreektaal van Moslems voorkom en waarvan baie gewortel is in die Moslemgeloof, is: kanalla (asseblief), trammakassie of sjukran (dankie), boeja (vader), oemi (moeder of ouma), madrasah (godsdienstige skool), koefia (fes) en labarang (Eid). Volgens Klopper (1983:287) hou die meeste van die woorde wat nog gebruik word, verband met sekere gesprekstemas, kledingstukke, eetgewoontes, die begrafnisritueel en die alledaagse bestaan.

Hendricks (2012b:addendum, 1996:8) en Saal en Blignaut (2011:352, 353) dui op tipiese leksikale merkers wat 'n relatief hoë gebruikfrekwensie het. Die woorde sluit in: entjies (sigarette), nwaatas praat (twak of nonsens praat), die gereelde gebruik van daai (daardie) en likes (hou van). Die uitdrukking nei/ nai man kom gereeld voor as ontkennende vorm, maar word ook gebruik as uitroep of 'n tipe stopwoord. Ander uitroepe wat frekwent gebruik word, sluit in awe (hallo), djy wiet né en lekke djy.

Saal en Blignaut (2011:353) dui ook op die gebruik van bestaande woorde in nuwe of uitgebreide betekenisse: Gevaa(r)lik, kwaai en duidelik in die betekenis baie, of wanneer iets of iemand goed is, bv. Haai man spiel gevaalik rugby; Roep in die betekenis van noem, Hulle roep hom Johnny; die woord getyg in die betekenis van praat, Kô getyg gou hie en ytstiek met die betekenis van opdaag, bv. Ik wil hê die ouens moet ytstiek ha. Die woord ve(r)sin kom gereeld voor in die betekenis van simpel of kinderagtig, bv. Djy's vesin. Die woorde spat en maats (Engelse march) is items wat kenmerkend is van Tienerkaaps en gebruik word in die betekenis van loop, bv. Lat ôs maats en Lat spat!

Kleinhans (1988), Hendricks (2012b:addendum) en Saal en Blignaut (2011:353) dui ook op die invloed van bendetaal op Kaapse slêng en Tienerkaaps: dala (baklei), ve'dala (doodmaak), wit biene (hy sterf), pakamisa (optel, weggaan, uitgaan of klaarmaak), zol (daggasigaret) en die uitroep minute! d.i. [monitə]. Die gebruik van nommers wat verwys na 'n persoon se lidmaatskap van 'n tronkbende waaronder ses en twintig, sewe en twintig en ag en twintig, kom ook gereeld voor.

Kaaps deel voorts ook volgens Hendricks (2012b:addendum) sekere woorde met flaaitaal, bv. mahala (verniet), sharp (goed, reg), gwarra (spot) en bra/blah (vriend).

De Vries (2006) en Le Cordeur (2013) dui op die volgende uitdrukkings wat kenmerkend van en eie is aan Kaaps. Moenie soe gaseg vekoepi (Moenie gunsies soek nie), Djy's 'n skets sône byskrifte (Jy's 'n nikswerd) en Ek it hom 'n kwai kaa(r)t geskiet (Draai hom 'n rat voor die oë).

Kleinhans (1988) stel dit dat Kaaps die "skeppendste variëteit van Afrikaans" is en dat Kaapse nuutskeppings gereeld spontaan na vore kom. Dit is 'n lewendige en dinamiese taal waar voortdurend nuwe leksikale items geskep word. Nuutskeppings waarop Saal en Blignaut (2011:353) dui, is onder meer dite [dait] wat eet beteken. Dit moet egter in gedagte gehou word dat nie alle leksikale items behoue bly in Kaaps nie, maar dat sommige woorde met verloop van tyd al minder gebruik word. 


\subsubsection{Morfologiese verskynsels}

Die vervlegting van Engels en Afrikaans in Kaaps vind ook neerslag in die woordvorming deurdat Engelse woorde op verskeie maniere verafrikaans word. Hendricks (2012b:addendum) dui op die morfologiese inbedding van Engelse ontlenings in die Afrikaanse verledetydsvorm bv. ge-apologise, ge-introduce en in samestellings, bv. hawkerkinners. Afrikaanse meervoudsvorming word volgens Kleinhans (1988) gereeld net so op Engelse woorde toegepas, bv. teame (teams) en bolle (balls).

Reduksie van sekere leksikale items is ook kenmerkend van Kaaps bv. som (sommige), daai (daardie), nodig (benodig) en van [fan] (want).

Ander morfologiese verskynsels waarop Hendricks (2012a:106, 2012b:addendum) dui, is die redundante gebruik van graadtrapmorfeme: bietere (beter); nie-emfatiese adjektiefverbuiging: mooie blomme, varse vis, valse tanne, die deur is oepe; die gebruik van it (dit) en is (dis) in sinsaanvangposisie en die gebruik van die besitlike voornaamwoord onse (ons) in attributiewe besitsposisie. Sekere werkwoorde gaan uit op 'n /e/ of 'n / $t /$ bv. beginne (begin), worre (word), skrywe (skryf) sowel as gaat (gaan) en siet (sien).

\subsubsection{Sintaktiese verskynsels}

Alhoewel McCormick (1993:66) dit stel dat die vernakulêre Afrikaans van die bruin mense in die Kaapse Skiereiland die meeste van die kenmerke van die sintaksis van Standaardafrikaans deel, dui Hendricks (2012a:106, 2012b:addendum, 1996:8) en Saal en Blignaut (2011:351, 352) op sintaktiese variasie wat in Kaaps voorkom.

Hendricks (1996:9) dui daarop dat Kaaps sintakties veral gekenmerk word deur die gebruik van reste uit ouer tale, bv. die hervatting van die onderwerp in die voornaamwoordelike vorm, bv. $P a$ hy werk baie hard en die gebruik van die besitlike voornaamwoord sy in plaas van se, bv. Die Here sy genade. Voorts is die gebruik van die voor 'n straat- of pleknaam bv. Ek bly innie Lavender Hill in asook die redundante gebruik van die bepaalde lidwoord voor substantiewe, kenmerkend van Kaaps, bv. Hy het die tiebie gahad. Die gebruik van vir as persoonsobjekmerker is ook tiperend van Kaaps, bv. Ek het vi hom gasê.

Wat woordorde betref, neem Kaaps die Engelse SVO (subject-verb-object)-woordordepatroon aan by bysinne en hoofsinne met 'n medewerkwoord, byvoorbeeld Hulle het gesteel my skoene (Hulle het my skoene gesteel). Werkwoordkonstruksies toon ook veral in die verledetydsvorm variasie, bv. het gevergeet, het geonthou, hy was geslaan (hy is geslaan).

Setselverdubbeling (identiese voorsetsel en agtersetsel) is ook 'n opvallende kenmerk van Kaaps, byvoorbeeld Ek bly innie Grassy Park in. Ook die herhaling van die onbepaalde lidwoord ' $n$ kom gereeld voor in Kaaps, byvoorbeeld Ek soek'n nog 'n sweet.

Die saam+met-konstruksie is volgens Saal en Blignaut (2011:351) kenmerkend van Kaaps en Tienerkaaps, byvoorbeeld Praat saam mit my. Hendricks (2012a:107) dui ook op die gebruik van die predetermineerder almal, uitgespreek amal, in plaas van al, bv. Amal die kinnes gan da wies. 
Kaaps is egter nie die enigste taalvorm wat te alle tye en in alle omstandighede deur die sprekers van Kaaps gebruik word nie, maar word afgewissel met ander tale en variëteite wat deel vorm van hulle taalrepertoire. Volgens Lüdi (2006:14) sluit die taalrepertoire van 'n persoon of gemeenskap verskillende tale, dialekte, registers en style in. Dit is die gevolg van interkulturele kommunikasie wat plaasvind tussen sprekers van verskillende tale.

Volgens McCormick (1993:66) kan die taalrepertoire van die inwoners van Distrik Ses in die negentigerjare beskou word as 'n spektrum waar Standaardengels aan die eenkant staan en Standaardafrikaans aan die ander kant. Dié taalrepertoire is egter nie net beperk tot die inwoners van Distrik Ses in die negentigerjare nie, maar kan tans ook beskou word as die taalrepertoire van alle sprekers van Kaaps. Williams (2012:54) stel dit dat die meertalige sprekers van Kaapstad se taalrepertoire ook isiXhosa, Tsotsitaal en Sabela insluit weens kontak met sprekers van hierdie tale.

Voorts bestaan daar ook volgens Hendricks (2012b:4) 'n wisselwerking tussen die gebruik van tipies Kaapse en gestandaardiseerde variante. Gevolglik sal 'n spreker albei vorme, bv. vi $x$ vir, siep $x$ seep, varse blomme $x$ vars blomme ens. afwisselend gebruik. Volgens Agha (in Williams 2012:54, 55) word elke register in die taalrepertoire geassosieer met spesifieke sosiale praktyke en met mense wat betrokke is in hierdie praktyke. Dit word dikwels gebruik in spesifieke ruimtes en plekke wat 'n kulturele groep, individue en sosiale praktyke definieer.

Agha stel in 2003 die term "enregisterment" (taalerkenning) bekend om te verwys na die proses waartydens die kenmerkende vorme van taal, oftewel die register, sosiaal herken word as 'n aanduider van spreker-eienskappe by 'n populasie van taalgebruikers (Agha, 2005:38). Johnstone, Andrus en Danielson integreer in 2006 die begrip van registererkenning met Michael Silverstein se "orders of indexicality" (Silverstein in Johnstone, Andrus en Danielson 2006) om die proses te beskryf waartydens sekere kenmerke van 'n taal beskou word as merkers van sosiale klas en voortdurend verbind word met plek en sodoende erken word as 'n register (Adams 2009:115).

Dieselfde proses vind ook plaas in Afrikaans waar verskillende variëteite van Afrikaans deur Kaapssprekendes afgewissel word na gelang van die fisiese of sosiale ruimte waarin hulle hulself bevind en sodoende reflekteer sprekers hulle sosiale identiteit. Alle sprekers van Kaaps gebruik ook nie Kaaps eenvormig nie. Soos Anastasia de Vries in Hendricks (2012b:4) dit stel: "Die soort Kaaps wat jy praat is [...] 'n padkaart van die kulture en subkulture waaraan jy blootgestel is." Hiervolgens is die Kaapse variasie wat'n spreker gebruik 'n weerspieëling van die bepaalde religieuse oriëntasie, ouderdom, sosiale klas en graad van geletterdheid van die spreker.

\section{Diglossie}

Ponelis (2009:2) definieer diglossie as "twee skerp verskillende taalvorme wat in afwisseling, naas mekaar, deur 'n taalgemeenskap gebruik word, een vorm meer formeel, die klassieke variëteit en die ander, die demotiese variëteit, minder formeel." Die gevolg is twee wyd uiteenlopende variëteite binne 'n taal.

Volgens Ponelis (2009:1) is die woord demoties “afgelei van die Griekse woord 'demos' wat 'volk' beteken. Onder 'demoties word dus verstaan 'volksaardig, populêr'." 'n Demotiese 
variëteit of taal kan dus beskou word as 'n populêre taal wat volgens Coulmas (2005:127) en Holmes $(1992: 34,37)$ as 'n omgangstaal by die huis, in die straat, vir skinderpraatjies, inkopies en in ander informele kontekste gebruik word. Dit is die taalvorm wat gewoonlik in die gesproke vorm voorkom en gebruik word vir storievertelling, maar kan ook in die geskrewe vorm voorkom. Dit vertoon intimiteit en solidariteit tussen die sprekers.

Daarenteen is die klassieke variëteit die formele taalvorm wat geassosieer word met mag. Dit is die taalvorm wat gestandaardiseer is en gebruik word in die geskrewe vorm, in openbare toesprake, vir religieuse doeleindes, in die opvoedkunde, normaalweg in die koerant en in nuusberigte en in ander formele kontekste. Literatuur word ook gewoonlik in die klassieke variëteit geskryf en dit is die taalvorm wat gestandaardiseer is en voortdurend gekodifiseer word in woordeboeke en taalhandboeke.

Demotiese Afrikaans het baie vorme, waarvan Kaapse Afrikaans slegs een is. Die verskil tussen Kaaps en demotiese Afrikaans is dat demotiese Afrikaans deur die hele taalgemeenskap versprei is, terwyl Kaaps deur slegs 'n spesifieke groep sprekers in die Wes-Kaap gebruik word. Een van die prominentste kenmerke van demotiese Afrikaans is die hoë mate van Engelse invloed en alhoewel die meeste omgangstaalvorme van Afrikaans Engelse invloed toon, dui Ponelis (2009:4) daarop dat die graad van Engelse invloed op demotiese Afrikaans, veel hoër is as in die gewone omgangstaal. Die hoë mate van Engelse invloed is dan ook 'n kenmerk van Kaapse Afrikaans.

Alhoewel demotiese Afrikaans aanvanklik 'n mondelinge taalvorm was, dui Ponelis (2009:4) daarop dat dit in die redelik onlangse verlede tot'n geskrewe taalvorm ontwikkel het. Dit het aanvanklik in die literatuur neerslag gevind in die werke van Adam Small wat in een van die vorme van demotiese Afrikaans, nl. Kaaps, geskryf het. Heelwat ander skrywers soos Peter Snyders en Loit Sôls het in sy spore gevolg. Vandag vind die gebruik van demotiese Afrikaans ook in die media neerslag deur die gebruik van 'n vorm van Kaaps in Son. Volgens Van der Rheede (2011:4) vind diglossie ook in Son plaas deurdat die demotiese variëteit in Son afgewissel word met die klassieke variëteit, nl. Standaardafrikaans.

\section{Die taalgebruik in die poniekoerant Son}

\subsection{Metode van ondersoek}

Verskeie Son-artikels uit koerante wat verskyn het in die tydperk tussen Desember 2011 en Oktober 2013 is geanaliseer om te bepaal tot watter mate Kaapse merkers voorkom in die koerant en in die artikels en of die taalgebruik in Son beskou kan word as 'n ware weerspieëling van Kaaps. Die uitgawes is lukraak geselekteer en die koerant is in die geheel geanaliseer in 'n poging om te bepaal of die taal wat gebruik word in die artikels, verband hou met die inhoud of aard van die artikel.

Die vermenging van Afrikaans met Engelse woorde en uitdrukkings word beskou as een van die algemeenste kenmerke van Kaaps, soos bespreek by 3.2.2. Interessant is die feit dat dit ook een van die algemeenste kenmerke van die taalgebruik in Son is. Om dié rede word die taalgebruik in Son deur lesers, akademici en joernaliste bloot as Kaaps aanvaar sonder dat dit krities geanaliseer word. Die gebruik van Engelse woorde en uitdrukkings in 'n teks met 'n 
oorwegend Afrikaanse karakter, kan egter ook as demotiese Afrikaans beskou word, soos bespreek onder diglossie.

Die gebruik van Engelse woorde en uitdrukkings is volop in sommige Son-artikels en daarom kan die Afrikaans wat in die koerant gebruik word, in aansluiting by Van der Rheede (2011) ook as demotiese Afrikaans beskou word. Die vervlegting van Afrikaans en Engels is egter slegs een kenmerk van Kaaps en die vraag wat gevolglik ontstaan, is of die taalgebruik wat in Son voorkom, Kaaps is en nie bloot 'n informele demotiese Afrikaans nie?

\subsection{Linguistiese merkers van Kaaps in Son}

\subsubsection{Leksikale verskynsels}

\subsubsection{Direkte ontlenings uit Engels}

Engelse woorde en uitdrukkings wat direk uit Engels ontleen is, kom gereeld voor in sommige Son-artikels. Die onderstaande uittreksels uit artikels, koppe en onderskrifte by foto's toon die verskynsel:

1. Hulle is nou wel klein, maar is gaga oor Son en die rol wat hulle favourite koerant in die fight teen drugs speel. (Son, 16 Februarie 2012, p.3)

2. Terwyl die cops verlede week ten minste vier gang-leiers gearresteer het, het tienerbendelede na bewering verskeie jong mense vermoor. (Son, 8 Mei 2013, p.2)

3. "Die counsil kan mos ons subsidy wegvat en eerder vir ons grond gee." (Son, 31 Oktober 2012, p. 6)

4. Departement wil 'n meeting hou oor safety (Son, 1 November 2012, p.1)

5. "Ons moet duck and dive in ons huise soos die koeëls vlieg." (Son, 7 Mei 2013, p.2)

6. Die enjin is 'n 4EFTE 1300GT Turbo unit met dictator enjin management, $63 \mathrm{~mm}$ exaust en ' $\mathrm{n}$ front mounted intercooler. Doni is ook trots op sy $50 \mathrm{~mm}$ boost pipes, 60 2 wasted spark setup en twee external brandstofpompe. (Son, 11 Oktober 2013, Bylae: Son wiele, p.5)

Engelse woorde wat verband hou met spesifieke domeine of onderwerpe soos die regstelsel, die polisie, dwelmverwante onderwerpe en sosiale en maatskaplike kwessies, word gereeld in beriggewing gebruik eerder as die Afrikaanse ekwivalent. Dit sluit aan by Klopper (1983:286) se beskouing van die gebruik van Engelse woorde in Kaaps wat by 3.2.2 bespreek is. Engelse woorde wat frekwent in artikels gebruik word is lawyer, bail, witness, cop, metro cop, van, drugs, gang, gangster, gun, rape, kids, council, officials, community, meetings en job. Op die skinderblad word die Engelse woorde fan, show, event, song en celebrity gereeld bo die Afrikaanse ekwivalente gebruik. Verder word gevoelswoorde ook eerder in Engels geskryf as in Afrikaans, bv. disgrace, useless, favourite, ens. Die artikels in die bylae, Son wiele, toon veral 'n hoë mate van Engelse invloed deurdat woorde wat verband hou met motoronderdele en motordienste, direk uit Engels oorgeneem word. In sommige gevalle is die frekwensie waarteen Engelse woorde gebruik word, so hoog, dat die sin nie meer'n Afrikaanse karakter toon wat die woordeskat betref nie, maar eerder 'n Engelse karakter aanneem (sien nommer 6 by die voorbeeldsinne). 


\subsubsection{Verafrikaansing van Engelse woorde en uitdrukkings}

Engelse woorde wat klankmatig verafrikaans is, vind ook neerslag in sommige artikels van Son, soos gesien kan word in die volgende voorbeelde uit verskillende uitgawes van Son:

1. Die spietkop is blykbaar gewurg en met 'n skêr gesteek. (Son, 8 Mei 2013, p.5)

2. Niemand op die plaas-lorrie het die trein fluitjie gehoor nie. (Son, 31 Oktober 2012, p.2)

3. Toni eet net wit tjoklits (Son, 15 Desember 2011, p.1)

4. Hy's bereid om baie legal fees te hoes omdat hy Krismis by sy huis wil wees. (Son, 15 Desember 2011, p.5)

Engelse uitdrukkings wat verafrikaans word deur die oorskakeling na Afrikaanse woorde in die uitdrukking en die direkte vertaling van 'n gedeelte van die uitdrukking uit Engels in Afrikaans, kan in die onderstaande uittreksels uit verskeie artikels en koppe, rubrieke en onderskrifte by foto's gesien word:

1. Toni Braxton het 'n chip op haar skouer (have a chip on one's shoulder) ná Oprah Winfrey se opmerkings. (Son, 1 November 2012, p.16)

2. Kameel sê vir Son Abrahams trek haar nou 'n lelike dirty (do the dirty on someone). (Son, 16 Februarie 2012, p.7)

3. Antie hoop die ander wat nes jy operate, vat note (take note). (Son, 31 Oktober 2012, p.26)

Onidiomatiese direkte vertaling uit Engels vind ook soms neerslag in die artikels, maar kom weinig voor en hou gewoonlik verband met die direkte woorde van die Kaapssprekende bron, 'n leser of ander kommentator en word byna nooit deur die joernalis in die beriggewing gebruik nie. Enkele voorbeelde hiervan sluit in:

1. "Ek wou die papiere (dokumente) sien en sy kon dit nie toon nie." (Son, 16 Februarie 2012, p.7)

2. "Ek sal eers met Waldeck moet praat om te luister (hoor) of hy kans sien om voort te gaan met die peace talks." (Son, 14 Mei 2013, p.4)

3. Maak pad (gee pad)! (Son, 11 Oktober 2013, Bylae: Son wiele, p.4)

Dit is dus duidelik dat Engelse woorde teen 'n hoë frekwensie gebruik word in Son en dat die invloed van Engels op Afrikaanse woorde en uitdrukkings, soos gekenmerk deur Kaaps, ook neerslag vind in die taalgebruik van Son.

\subsubsection{Kaapse uitdrukkings}

Buiten vir die hoë mate waarmee Engelse woorde met die Afrikaanse taalgebruik vermeng word, vind Kaapse uitdrukkings en woorde ook neerslag in die artikels, koppe en onderskrifte by foto's soos gesien kan word uit die volgende voorbeelde uit verskeie uitgawes van Son:

1. Laaities van 15 en 16 jaar oud is besig om oor te vat by die dikdinge (leiers) in die bende. (Son, 8 Mei 2013, p.2)

2. Matriekmeisie en haar ou met skote in die kop afgehaal (vermoor) (Son, 7 Mei 2013, p.1) 
3. "Hulle het net gesê dis Wynberg se probleem en onmiddellik weer gepak (geloop)." (Son, 7 Mei 2013, p.6)

4. "Ons kla van laas kwartaal af oor die jongens (seuns) wat ons kinders voorlê." (Son, 1 November 2012, p.2)

5. Minnies het toe aan die cops gesê "dis nie kwaai (lekker) nie" (Son, 11 Oktober 2013, p.6)

6. Dansonnie mang (gaan tronk toe) lewenslank na rape (Son, 1 November 2012, p.2)

7. Toe hy by haar kom, het sy snaaks opgetree en die cop het vermoed sy is getik (gebruik die dwelm tik). (Son, 1 November 2012, p.4)

8. Guys sê dis toe dat sy hoor hoe die gattas (polisie) brag oor hoe hulle hom gemoer het. (Son, 11 Oktober 2013, p.3)

9. $\quad$ Laaities lem (steek met' $n$ mes) terug (Son, 1 November 2012, p.1)

10. Burger King in Kaapstad kan dalk eersdaags baie van sy kroon (geld) verloor as 'n groep Moslems hulle dreigement uitvoer om die franchise te boikot. (Son, 14 Mei 2013, p.5)

Kaapse woorde wat gereeld voorkom in Son-artikels is woorde wat verband hou met die dwelm tik, bv. tikkop, getik, tiklollie. Die woord laaities of jongens om te verwys na seuns en die Kaapse woord mang, wat verwys na tronk toe gaan en ook die invloed van bendetaal toon, kom ook gereeld voor. Bestaande Afrikaanse woorde wat kenmerkend van Kaaps is, word in nuwe of uitgebreide betekenisse gebruik. Voorbeelde hiervan wat soms in Son-artikels neerslag vind, sluit onder andere in spat of pak (loop) en kwaai (goed/lekker).

Voorbeelde van kenmerkende Kaapse uitdrukkings wat voorkom, sluit in:

1. Kind, kan jy nie sien hoe daai jong jou vir'n pop vat nie (' $\mathrm{g}$ gek van jou maak). (Son, 2 November 2012, p.34)

2. Die werkers het'n lange gegooi (weggeloop) toe hulle oor hulle besem gekonfronteer is. (Son, 7 Mei 2013, p.6)

3. City vat ons vir'n joke (maak'n gek van ons). (Son, 16 Februarie 2012, p.2)

4. Van 2 tot 4 Maart gaan die ding ruk (dinge gaan plesierig raak). (Son, 16 Februarie 2012, p.2)

Die Kaapse woorde en uitdrukkings vind neerslag in die direkte woorde van die bronne wat by die artikel betrokke was of die lesers en ander kommentators, maar kom ook voor in die verslaggewing deur die joernalis self. Veral die teemtante-rubriek, Moan by Antie Mona, bevat heelwat Kaapse uitdrukkings in die briewe wat deur lesers geskryf word, sowel as die antwoorde op die briewe. Ook die koppe en subopskrifte van artikels bevat gereeld Kaapse elemente en skep die indruk dat die Kaapse uitdrukkings gebruik word om aandag te trek. Die frekwensie van die gebruik van Kaapse woorde is egter baie minder as die gebruik van Engelse woorde of woorde wat Engelse invloed toon. Alhoewel dit dus voorkom in Son-artikels, toon nie alle artikels 'n Kaapse kleur nie. Arabiese woorde wat deel vorm van die Moslemkultuur en gevolglik ook deel vorm van Kaaps, kom egter selde voor in Son.

\subsubsection{Morfologiese verskynsels}

Wat die morfologiese aard van die taalgebruik in Son betref, kom Engelse woorde voor wat verafrikaans word deur die morfologiese inbedding van Engelse ontlenings in die verledetydsvorm. Voorbeelde hiervan sluit die volgende in: 
1. Die familie voel Kyle word nou ge-judge op onwaarhede, en mense moet liewer wag vir die waarheid. (Son, 8 Mei 2013, p.5)

2. Sebastiaan is vermoedelik deur haar moordenaar daar ge-dump. (Son, 16 Februarie 2012, p.5)

3. Ge-bitch 'n ge-stitch (Son, 10 Januarie 2012, p.1)

4. Sy het deur die shop ge-cruise en kort daarna weer by die deur uitgestap. (Son, 11 Oktober 2013, p.10)

Die gebruik van samestellings tussen Engelse en Afrikaanse woorde, kom ook algemeen voor. Voorbeelde uit verskillende uitgawes van Son sluit in:

1. Kapt. Marie Louw sê die plek was eers 'n drug-huis wat verbeurd verklaar is. (Son, 8 Mei 2013, p.6)

2. Sedert Desember het 20 mense in die gangster-oorlog in dié dorp gesterf. (Son, 14 Mei 2013, p.4)

3. Die bende-peace talks is vir eers op ys. (Son, 14 Mei 2013, p.4).

Die morfologiese inbedding van Engelse ontlenings in die graadtrapmorfeme kom byna nooit voor nie. 'n Enkele voorbeeld sluit in:

1. Funky-ste Buddha kom (Son, 1 November 2012, p.17)

Kenmerkende morfologiese verskynsels van Kaaps kom nie algemeen voor in die artikels van Son nie. In die 12 uitgawes wat vir die doel van hierdie ondersoek geanaliseer is, het die reduksie van leksikale items soos die gebruik van som (sommige), nodig (benodig) en van (want), glad nie voorgekom nie. Ook die redundante gebruik van graadtrapmorfeme, byvoorbeeld bietere, oppere ens., en die nie-emfatiese adjektiefverbuiging, byvoorbeeld mooie, valse ens., is nie in die artikels gebruik nie. Voorts word die besitlike voornaamwoord, onse in attributiewe besitsposisies, ook nie gebruik nie.

\subsubsection{Sintaktiese verskynsels}

Sintaktiese merkers van Kaaps kom selde voor in Son, en is hoofsaaklik beperk tot die direkte woorde van die bronne wat betrokke was by die betrokke artikel. Die volgende voorbeelde dui op die Kaapse werkwoordkonstruksies in die verlede tyd:

1. “As hulle skollies gewees het, sou dit makliker gewees het om te aanvaar." (Son, 8 Mei 2013, p.2)

2. "Die stryery moet oor sy dogtertjie gegaan het, want hy is baie lief vir sy kind." (Son, 16 Februarie 2012, p.4)

'n Voorbeeld van sinne wat die SVO-woordordepatroon oorneem by Engels in gevalle waar bysinne voorkom of 'n hoofsin 'n medewerkwoord bevat, is die volgende:

1. Maar Kanye kan nie wil kwaad raak nie. (Son, 1 November 2012, p.17) 
Die gebruik van niks in die ontkenning is nog 'n sintaktiese verskynsel wat in Kaaps voorkom en is te bespeur in die volgende voorbeeld:

1. Getroude mammies is niks skaam vir affairs. ( Son, 8 Mei 2013, p.4)

Kenmerkende sintaktiese verskynsels van Kaaps, soos die gebruik van die voor 'n plek- of straatnaam, setselverdubbelling, die hervatting van die onderwerp in die voornaamwoordelike vorm, die gebruik van die besitlike voornaamwoord $s y$ in plaas van se, die gebruik van almal as predetermineerder sowel as die gebruik van vir as persoonsobjekmerker het glad nie voorgekom in die artikels wat vir die studie ondersoek is nie.

\subsubsection{Fonologiese verskynsels}

Tipiese Kaapse uitspraakverskynsels wat in die spelling van woorde neerslag vind, kom egter weinig voor in Son en is hoofsaaklik beperk tot die koppe of subopskrifte van artikels en word aangewend om aandag te trek, maar vind nie neerslag in die koerantartikels self nie. Enkele voorbeelde hiervan uit verskeie Son-uitgawes word hieronder aangedui ${ }^{3}$ :

1. Eazy, my kinnes (Son, 1 November 2012, p.29)

2. Druggies oppie stasie ry daagliks na nêrens (Son, 9 Desember 2011, p.1)

3. Grondeienaars bly oor 'pampiere' (Son, 14 Oktober 2013, p.7)

Die naam van die sosiale bladsy, lekke djy met Jill, gee ook die Kaapse uitspraakverskynsel van affrisering van die [j] klank in sillabe-beginposisie en die postvokaliese [r]-weglating, weer in die spelling van die naam van die blad. Buiten vir die spelling van die naam, is lekke djy ook 'n tipiese Kaapse uitdrukking. Die Kaapse uitspraak wat in die spelling weergegee word tesame met die gebruik van 'n Kaapse uitdrukking, verskaf 'n Kaapse kleur en informele styl aan die sosiale blad.

Die Kaapse spelling vind ook soms neerslag in die grappies en word aangewend vir humor, byvoorbeeld:

"Boetie, Mamma wag virrie aartappels, man. Vir wat huil djy nou - het somebody djou geskud?" "Nei, Sussie, issie dittie," sê Boetie. (Son, 16 Februarie 2012, p.14).

\subsection{Standaardafrikaans in Son-artikels}

Die taalgebruik in Son is egter nie net van informele aard nie, maar die demotiese of Kaapse Afrikaans word afgewissel met Standaardafrikaans. Sommige artikels word uitsluitlik in Standaardafrikaans geskryf. Hierdie artikels sluit veral sportberigte en harde nuus in wat ook in ander dagblaaie verskyn. In sulke gevalle word die hele artikel in Standaardafrikaans geskryf terwyl slegs die kop van die artikel in sommige gevalle Kaapse of demotiese Afrikaanse elemente bevat. In ander artikels word Standaardafrikaans vermeng met Engelse woorde of Kaapse uitdrukkings. Voorbeelde van Standaardafrikaans wat voorkom in Son is die volgende:

\footnotetext{
${ }^{3}$ Aangesien die fonologiese verskynsels voorbeelde is wat in Son-artikels verskyn het, word die uitspraak nie foneties weergegee nie, maar geskryf soos dit in die betrokke Son-artikel gespel is.
} 
1. Son verneem die polisie het reeds vroeër vir maatskaplike dienste gewaarsku oor die haglike omstandighede waarin die seuntjie geleef het. (Son, 16 Februarie 2012, p.2)

2. Die kinders was ten tyde van die voorval besig om buite te speel. (Son, 8 Mei 2013, p.5)

3. Cecil Brown (40), vermeende leier van die Mongrels, het gister vlugtig in die Wynberglanddroshof verskyn. (Son, 7 Mei 2013, p.5)

4. Die nypende tekort aan vaardige ambagsmanne hou negatiewe gevolge in vir dienslewering in die land. (Son, 15 Desember 2011, p.3)

5. Kapt. Marie Louw sê die plek was eers 'n drug-huis wat verbeurd verklaar is. (Son, 8 Mei 2013, p.6)

6. Snelaanval is giftigste sê Donald oor SA boulers (Son, 31 Oktober 2012, p.36)

7. Die kolf-ineenstorting het weer skokgolwe deur die land gestuur. (Son, 15 Desember 2011, p.47)

\section{Samevatting}

Volgens die ontleding van verskeie Son-artikels wat in hierdie studie bespreek is, is die bevinding van die studie in teenstelling met Edwin Lombard (persoonlike korrespondensie 2012) en De Vries (2012) se beskouing van die taalgebruik in die poniekoerant Son dat die taalgebruik nie as uitsluitlik Kaaps beskou kan word nie, maar dat daar eerder 'n diglossieverhouding bestaan tussen die Klassieke of Standaardafrikaans, demotiese Afrikaans en Kaapse Afrikaans aangesien die verskillende variëteite in afwisseling naas mekaar in die koerant gebruik word, hetsy binne een artikel of tussen verskillende artikels binne een uitgawe van die koerant of selfs in dieselfde sin.

Die taalgebruik in Son toon 'n hoë gebruiksfrekwensie van direkte Engelse ontlenings, sowel as woorde waarvan die invloed van Engels duidelik te bespeur is, soos die morfologiese inbedding van Engelse lemmas in die verledetydsmorfeem, samestellings tussen Afrikaans en Engelse woorde sowel as Engelse woorde wat klankmatig verafrikaans is. Dit alles is kenmerke van Kaaps.

Kaapse woorde en uitdrukkings kom ook voor in Son, maar die gebruiksfrekwensie is heelwat laer as dié van die Engelse woorde. Die Engelse woorde boyfriend en girlfriend word byvoorbeeld herhaaldelik gebruik in Son en verkies bo die Kaapse ekwivalent burk, motta of motjie. So ook word daar byna glad nie gebruik gemaak van Arabiese woorde wat verbind word met die Moslemkultuur en deel vorm van Kaaps nie.

Die Kaapse woorde en uitdrukkings wat voorkom in Son is hoofsaaklik beperk tot die direkte woorde van die bronne en lesers en tot' $n$ mindere mate dié van die verslaggewer. Die teemtanterubriek, Moan by Antie Mona bevat wel heelwat Kaapse elemente. Kaapse woorde en uitdrukkings word verder gereeld in koppe en subopskrifte gebruik en skep die indruk dat dit gebruik word om aandag te trek.

Die gebruik van Kaapse woorde en uitdrukkings hou verder verband met die aard van die artikel en spesifieke inhoud soos gemeenskapstories, skindernuus en stories van sensasionele aard. Daarenteen word Standaardafrikaans vir harde nuus en veral in sportberigte gebruik.

Kaapse elemente in die sinstruktuur van die artikels kom voor, maar baie selde en word slegs gebruik wanneer 'n Kaapssprekende bron se direkte woorde aangehaal word. Die sintaktiese 
variasie wat Kaaps toon soos bespreek by 3.2.4 (soos die herhaling van sekere woorde, die gebruik van die saam+met-konstruksie, die hervatting van die onderwerp in die voornaamwoordelike vorm, ens.) vind egter byna glad nie neerslag in die beriggewing van Son nie.

Morfologiese verskynsels van Kaaps vind ook weinig neerslag in die taalgebruik van Son. Dit is buiten die invloed van Engels op die morfologiese aard van Afrikaanse woorde. Die reduksie van sekere leksikale items, die redundante gebruik van graadtrapmorfeme, die nie-emfatiese adjektiefverbuiging en die gebruik van die besitlike voornaamwoord onse in plaas van ons in attributiewe posisie, soos bespreek by 3.2.3, is morfologiese verskynsels van Kaaps wat byna glad nie neerslag vind in die taalgebruik van Son nie.

Die fonetiese variasie van Kaaps kom ook selde voor in die spelling van woorde in Son en word slegs nou en dan gebruik in byvoorbeeld 'n grappie of 'n opskrif waar die spelling in verband gebring kan word met' $n$ aanhaling in die berig of aandag wil trek.

Die manier waarop Kaaps in Son uitgebeeld word, is dus beperk tot woordgebruik en Kaapse uitdrukkings, sowel as die vermenging van Afrikaans en Engels, wat op sy beurt ook as demotiese Afrikaans beskou kan word. Om die rede kan die taalgebruik in Son nie beskou word as 'n ware weerspieëling van Kaaps soos wetenskaplik beskryf en gepraat word deur die sprekers van Kaaps nie.

Die kritiek wat Willemse (2012) jeens die gebruik van Kaaps in die letterkunde het, kan ook op Son van toepassing gemaak word aangesien Kaaps ook "formule-agtig" uitgebeeld word siende dat daar slegs op een aspek gefokus word, nl. die leksikale variasie en spesifiek die hoë gebruiksfrekwensie van Engelse woorde. Daar is egter baie ander strategieë wat aangewend kan word om 'n ware weerspieëling van Kaaps in die poniekoerant, Son te gee, soos om ook aandag te gee aan Kaapse sinskonstruksie, morfologiese kenmerke van Kaaps aan te wend en die fonologiese kenmerke van Kaaps in die spelling weer te gee. Kenmerkende Kaapse woorde en idiomatiese taalgebruik kan ook meer frekwent gebruik word.

Alhoewel die taalgebruik in Son nie as uitsluitlik Kaaps, soos beskryf word deur taalkundiges en aangewend word in die literatuur, beskou kan word nie, kan die taalgebruik in Son wel beskou word as 'n refleksie van die manier waarop Kaaps deur sy sprekers afgewissel word met Standaardafrikaans en demotiese Afrikaans. Soos vroeër bespreek is die taalrepertoire van Kaapssprekendes nie beperk tot Kaaps nie, maar sluit dit verskillende tale, registers en variëteite in. Die wisselling tussen Standaardafrikaans en Kaaps en 'n formele en informele styl in die beriggewing, kan daarom beskou word as 'n poging om die taalrepertoire van die Kaapssprekende gemeenskap sover moontlik te probeer weergee. Voorts kan die diglossie wat voorkom in Son, ook beskou word as 'n poging om die verhouding van diglossie wat bestaan in die omgangstaal van Kaapssprekendes in die beriggewing uit te beeld.

Die taalgebruik in Son neem egter ook sosiale betekenisse en assosiasie aan en skakel, in ooreenstemming met Agha (2003) se registererkenning, met 'n spesifieke plek en sosiale identiteit. Die taalgebruik in Son speel dus 'n rol in die registererkenning van die taalgebruik van die bruin mense wat in die Kaapse Skiereiland woon. Alhoewel die studie toon dat die taalgebruik in Son nie 'n ware weerspieëling van Kaaps is nie, beïnvloed die manier waarop Kaaps in sommige artikels van Son neerslag vind, mense se persepsie van Kaaps, oftewel die 
taalgebruik van die bruin mense in die Kaapse Skiereiland, en hulle denke oor die kulturele waardes wat aan hierdie taalvorm geheg word. Gevolglik word Kaaps geassosieer met die Kaapse Vlakte en met 'n gemeenskap uit 'n lae sosiale klas.

Soos reeds genoem, gebruik alle sprekers van Kaaps nie Kaaps eenvormig nie, maar word hulle taalgebruik beïnvloed deur die spreker se agtergrond, opleiding, ouderdom en ander sosiale faktore. Baie lesers sal dus uitgesluit word indien Son slegs 'n spesifieke vorm van Kaaps gebruik. Deur die gebruik van Standaardafrikaans, demotiese Afrikaans en Kaaps, sluit die taalgebruik nie slegs Kaapssprekendes in nie, maar ook die groter Afrikaanse taalgemeenskap en is die koerant sodoende meer inklusief.

\section{Slotopmerking}

Die bevinding van die studie is dat die taalgebruik in Son nie 'n ware weerspieëling van Kaaps is nie, maar dat sommige artikels wel Kaapse merkers bevat. Wanneer die taalgebruik in die koerant in geheel beskou word, kan dit beskou word as 'n poging om die verhouding van diglossie tussen Standaardafrikaans, demotiese Afrikaans en Kaapse Afrikaans, wat in die omgangstaal van Kaapssprekendes bestaan, weer te gee sowel as om die taalrepertoire van die lesers in die taalgebruik van Son te reflekteer. Deur dit te doen, spreek die taalgebruik van Son tot 'n groter gehoor en is dit dus meer toeganklik vir 'n groter groep lesers, ongeag die soort Kaaps of Afrikaans wat hulle gebruik.

\section{Bronnelys}

Ads24. 2012. [Internet]. Beskikbaar: http://www.ads24.co.za/publication. (7 November 2012).

Adams, M. 2009. Enregisterment: A special issue. American Speech 84(2): 115-117.

Agha, A. 2003. The social life of cultural value. Language \& Communication 23: 231-273.

Agha, A. 2005. Voice, footing, enregisterment. Journal of Linguistic Anthropology 15(1): 38-59.

Biressi, A en Nunn, H. 2008. The tabloid culture reader. Berkshire: Open University Press.

Botha, T.J.R. 1989. Afrikaans sedert die negentiende eeu. In T.J.R. Botha, F.A. Ponelis, J.G.H. Combrinck, en F.F. Odendal (reds.). Inleiding tot die Afrikaanse Taalkunde (Tweede Hersiene Uitgawe). Pretoria: Academia. pp. 127-154.

Botha, M. 2009. Die geelpers in Suid-Afrika. 'n Analise van die Kaapse Son, Daily Voice en Daily Sun. Ongepubliseerde magistertesis. Universiteit Stellenbosch.

Coetzee, A. 2005. Dialekmerkers in Afrikaanse literatuur. Tydskrif vir Taalonderrig 39(1): 3550 .

Coulmas, F. 2005. Sociolinguistics. The study of speakers' choices. New York: Cambridge University Press. 
Deumert, A. 2004. The unbearable lightness of being bilingual: English-Afrikaans language contact in South Africa. Language Sciences 27: 113-135.

De Vries, A. 2006. Kaaps, taal van my hart. Rapport, 23 Julie.

De Vries, A. 2012. Kaaps in koerante. Lesing gelewer tydens simposium Kaaps in fokus, 1920 Julie 2012, Universiteit van Wes-Kaapland, Bellville.

Erasmus, D. 2006. Funksies van taalvariasie in die Afrikaanse toneelkuns. Ongepubliseerde Magisterverhandeling. Universiteit van Stellenbosch.

Hendricks, F.S. 1978. 'n Sinchronies-diachroniese studie van die taalgebruik in die drama Kanna hy kô hystoe van Adam Small. Ongepubliseerde magistertesis. Universiteit van WesKaapland.

Hendricks, F. 1996. Kaaps: afwisseling met Engels is spontaan. Afrikaans Vandag, September 1996: 8-9.

Hendricks, F. 2012a. Om die miskende te laat ken. 'n Blik op Adam Small se literêre verrekening van Kaaps. Tydskrif vir Letterkunde 49(1): 95-114.

Hendricks, F. 2012b. Die aard en konteks van Kaaps: 'n Verledetydse, eietydse en toekomsperspektief. Lesing gelewer tydens simposium Kaaps in fokus, 19-20 Julie 2012, Universiteit van Wes-Kaapland, Bellville.

Holmes, J. 1992. An introduction to sociolinguistics. New York: Longman.

Johnstone, B., Andrus, J. en Danielson, A.E. 2006. Mobility, indexicality, and the enregisterment of "Pittsburghese." Journal of English Linguistics 34: 77-101.

Kleinhans, H. 1988. Kaaps kan dalk 'standaard' oorleef. Die Burger, 23 Maart.

Klopper, R.M. 1983. Taalsisteemvariasie in Kaapse Afrikaans. In A.J.L. Sinclair (red.). G.S. Nienaber-'n huldeblyk. Studies opgedra aan prof. G.S. Nienaber in sy tagtigste jaar. Kaapstad: UWK Drukkery. pp. 275-296.

Le Cordeur, M. 2013. Kaaps is 'straight en diep'. Die Burger, 8 Augustus.

Lüdi, G. 2006. Multilingual repertoires and the consequences for linguistic theory. In K. Bührig en J.D. Ten Thije (reds.), Beyond misunderstanding: Linguistic analyses of intercultural communication. Amsterdam: John Benjamins. pp. 11-42.

Matthews, W. 2009. Multimodality and negotiation of Cape Flats identity in selected Daily Voice front pages. Ongepubliseerde magistertesis. Universiteit van Wes-Kaapland.

McCormick, K. 1993. Language shift in District Six: Snapshots and frames. PsiCL 28: 65-78. 
Örnebring, H en Jönsson, A. 2008. Tabloid journalism and the public sphere: a Historical perspective on tabloid journalism. In A. Biressi en H. Nunn (reds.). The tabloid culture reader. Berkshire: Open University Press. pp. 23-33.

Ponelis, F. 2009. Die taal wat ons praat. Die Burger, 18 Desember.

Saal, E.O. en Blignaut, J. 2011. "Moetie rai gammattaal gebrykie": Die gebruik van Kaapse Afrikaanse tienertaal in gedrukte advertensies. Litnet. [Internet]. Beskikbaar: http://www.litnet.co.za/assets/pdf/13 Saal en Blignaut.pdf. (7 Februarie 2012).

Smith, A. 2012. Son, Storie van 'n superheld. Taalgenoot, Winter 2012.

Son, 18 Januarie 2011. Kaapstad: Media24

Son, 23 Januarie 2011. Kaapstad: Media24.

Son, 24 Januarie 2011. Kaapstad: Media24.

Son, 9 Desember 2011. Kaapstad: Media24.

Son, 15 Desember 2011. Kaapstad: Media24.

Son, 10 Januarie 2012. Kaapstad: Media24.

Son, 16 Februarie 2012. Kaapstad: Media24.

Son, 31 Oktober 2012. Kaapstad: Media24.

Son,1 November 2012. Kaapstad: Media24.

Son, 2 November 2012. Kaapstad: Media24.

Son, 7 Mei 2013. Kaapstad: Media24.

Son, 8 Mei 2013. Kaapstad: Media24.

Son, 14 Mei 2013. Kaapstad: Media24.

Son, 11 Oktober 2013. Kaapstad: Media24.

Son, 14 Oktober 2013. Kaapstad: Media24.

Van der Rheede, C. 2011. Die rol van Afrikaanse poniekoerante soos die Son in die ontsluiting van die sosiale, opvoedkundige en ekonomiese waarde van Kaapse Vernakulêre Afrikaans. Litnet. [Internet]. Beskikbaar: http://www.argief.litnet.co.za/cgi-bin/giga.cgi?cmd=cause dir news item\&cause id=1270\&news id=98769. (22 Februarie 2011). 
Van Rensburg, C. 2010. Vloei en stroomversnellings: Fritz Ponelis en die Afrikaanse Taalkunde. Lesing gelewer tydens Eerste Fritz Ponelis-gedenklesing, 28 Julie 2010. Taaloord. [Internet]. Beskikbaar: http://www.taaloord.co.za/ Gedenklesing_Ponelis.pdf. (5 Mei 2011).

Van Rensburg, M.C.J. 1989. Soorte Afrikaans. In T.J.R. Botha, F.A. Ponelis, J.G.H. Combrinck en F.F. Odendal (reds.). Inleiding tot die Afrikaanse taalkunde. Pretoria: Academica. pp. 436467.

Van Rensburg, M.C.J. (red.). 1997. Afrikaans in Afrika. Pretoria: J.L. van Schaik.

Willemse, H. 2012. Soppangheid vir Kaaps: Oor mag, kreolisering en Kaapse Afrikaans. Lesing gelewer tydens simposium Kaaps in fokus, 19-20 Julie 2012, Universiteit van Wes-Kaapland, Bellville.

Williams, Q. 2012. The enregisterment of English in rap braggadocio: a Study from EnglishAfrikaans bilingualism in Cape Town. English Today 28(2): 54-59. 